\title{
Gall's Visit to The Netherlands
}

\author{
PAUL ELING,${ }^{1}$ DOUWE DRAAISMA, ${ }^{2}$ \\ AND MATTHIJS CONRADI ${ }^{3}$
}

\author{
${ }^{1}$ Radboud University of Nijmegen, Donders Institute for Brain, Cognition and \\ Behaviour, Nijmegen, The Netherlands \\ ${ }^{2}$ Department of Psychology, State University of Groningen, The Netherlands \\ ${ }^{3}$ Science and Technology Writer, Groningen, The Netherlands
}

\begin{abstract}
In March 1805, Franz Joseph Gall left Vienna to start what has become known as his cranioscopic tour. He traveled through Germany, Denmark, and The Netherlands. In this article, we will describe his visit to The Netherlands in greater detail, as it has not yet received due attention. Gall was eager to go to Amsterdam because he was interested in the large collection of skulls of Petrus Camper. Gall presented a series of lectures, reports of which can be found in a local newspaper and in a few books, published at that time. We will summarize this material. We will first outline developments in the area of physiognomy, in particular in The Netherlands, and what the Dutch knew about Gall's doctrine prior to his arrival. We will then present a reconstruction of the contents of the lectures. Finally, we will discuss the reception of his ideas in the scientific community.
\end{abstract}

Keywords Gall, The Netherlands, localization, $19^{\text {th }}$ century, phrenology

\section{The Physiognomical Background in The Netherlands and Gall's Tour to The Netherlands}

The word "physiognomy" refers to the "science" of reading someone's character from his outlook, in particular the face. Francis Bacon described it as "discovery of the disposition of the mind by the lineaments of the body" (Bacon, 1994, p. 81). Physiognomy can be traced back to Aristotle. He wrote extensively about comparisons between animal and human characteristics. The book Physiognomonica was believed to be written by Aristotle for a long time, but we now think it was one of his followers (Jahnke, 1997). Within this text, one can find descriptions of the basic methodology of physiognomy. For instance, physiognomic analysis should begin with the delineation of distinct, external features of the body and then relate these characteristics to specific personality types.

In the middle ages, physiognomy became linked to mystical and astrological theories. An encyclopedic work, referred to frequently well into nineteenth-century texts, is Giovanni Battista della Porta's (1535-1615) De Humana Physiognomonia from 1586. In the middle of the eighteenth century it became somewhat obscure and George II made it illegal in 1743. However, in 1793 Johann Kaspar Lavater (1741-1801), a minister in Zürich

The authors would like to thank Linda Isaac for her help and comments on an earlier version of this article.

Address correspondence to Dr. Paul Eling, Radboud University of Nijmegen, Donders Institute for Brain, Cognition and Behaviour, P.O. Box 9104, 6500 HE Nijmegen, The Netherlands. E-mail: p.eling@donders.ru.nl 
revitalized the tradition with his Physiognomische Fragmente (Lavater, 1775-1778), which was translated in English as Essays on Physiognomy.

\section{Petrus Camper (1722-1789)}

The Dutch were also familiar with the physiognomic tradition. Petrus Camper was well known for his anthropological studies and in particular for his studies on the "facial angle" (see Figure 1). Camper was born in 1722 in Leiden (Schuller tot Peursum-Meijer \& Koops, 1989). In 1734, he was admitted to the university. Boerhaave and Gravesande's, friends of the family, provided him with a thorough training. He finished his studies in 1746 with a double dissertation and became a physician in Leiden. In 1748, he coordinated an academic tour, visiting London and Paris. He returned to Holland in 1749 and accepted a chair at the University of Franeker. In 1754, he moved to the "Illustre School" of Amsterdam. Anatomy was his greatest passion and Amsterdam offered him much more facilities to work in this discipline. In 1761, he returned to Franeker. From 1763 to 1773 he lectured at the University of Groningen: theoretical medicine, anatomy, surgery, and botany, and he was also involved in more applied medical projects. In 1773, he returned again to Franeker and, after several years as an unemployed civilian, he directed his attention towards politics. He died in 1789. Camper has been characterized as follows: He has worked in many different areas of science, but he did not advance one of them.

A central notion in Camper's work is analogy; Camper believed in some underlying uniformity in nature. He particularly disliked the approach of Linnaeus. His interest in the underlying structural similarities resulted in studies in which he compared the human body with that of animals. He also analyzed differences between humans from different continents. Because the Dutch often sailed across the oceans, it was an optimal opportunity to "collect" evidence. In 1767, he began to work on a manuscript entitled Natuurkundige Verhandeling over het verschil in de wezenstrekken in Menschen van onderscheidene landaart en ouderdom (Natural essay on the difference in character in men from different countries and age). The manuscript was published in 1795 by his son after Camper's death. In this paper, Camper reported on craniometric studies. He developed a method to measure differences in size of different aspects of the skull. He argued that the facial angle

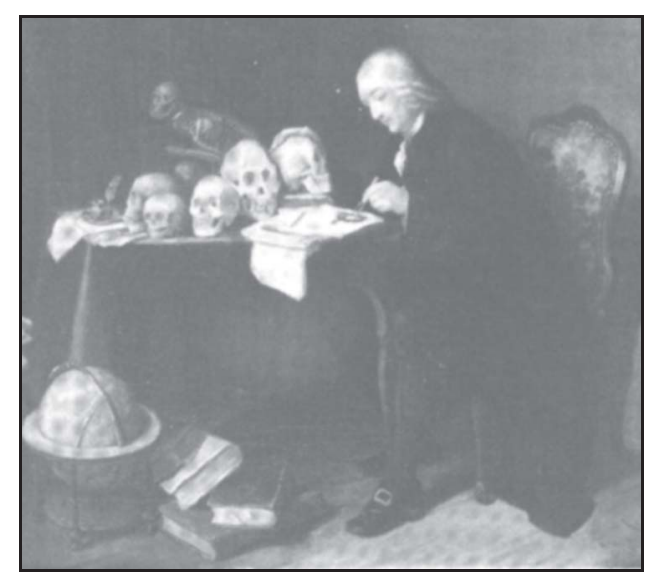

Figure 1. Petrus Camper. 
was especially important: The angle is formed by drawing two lines: one horizontally from the nostril to the ear and the other perpendicularly from the advancing part of the upper jawbone to the most prominent part of the forehead. He asserted that the larger the angle, the higher the degree of development. The method Camper used to make drawings was not his original technique. Albrecht Dürer (1471-1528) had used it, as well as the physician Bernard S. Albinus (1697-1770), working in Leiden. Camper specifically applied this method for measurement of the skull to comprehend the differences in intellectual capabilities.

Of particular interest in these days was the comparison between humans and orangutans. The well-known Dutch physician Nicolaas Tulp had introduced the anatomical study of this animal, referred to him also as Satyrus Indicus in the literature (Kruger, 2005). Because of the good opportunities to get materials from remote areas, Camper had been able to get skulls from orangutans. He became internationally famous with this study, and when Gall took the trouble to travel from Amsterdam to Franeker, as we will describe later, he did not go to visit Camper, since he had died, but he was interested in the skull collection, in particular of those of the apes.

\section{Lavater's Physiognomy in The Netherlands}

In the 1780s, Lavater's work became popular in The Netherlands (Lavater, 1780) and several books were published describing Lavater's ideas (see also Noordhoek, 1925). In 1780, the Physiognomische Catechismus, bevattende de gronden en beginselen der Gelaadkennis (Physiognomic catechism, containing the reasons and principles of physiognomy) was published by an anonymous author in Amsterdam (Anonymous, 1780). Pieter den Hengst published a translation of Daniel Chodowiecki's (1781) book (see Figure 2). Chodowiecki (1726-1801) was a Polish-German painter and was most famous as an etcher. He produced many illustrations for scientific books. Originally, Chodowiecki had published his critical essay in 1777, and an expanded version was printed the following year; den Hengst's book is a translation of the latter. Chodowiecki argues that there is no consistent relation between the character of the soul and features of the body. An individual may behave normally and suddenly may become aggressive. Moreover, the wide variety of appearances in peoples around the world cannot be associated with their characters. According to Chodowiecki, Lavater's work is on pathognomic features rather than physiognomic features. And finally, he complains that there are so few examples of women in Lavater's book.

Although Chodowiecki had been critical, Lavater had been positive about the book and apparently the Dutch readers were encouraged to become acquainted with it. In 1784, J. W. Haar published the second edition of his translation of Lavater's major work. This edition contains a list of over 500 subscribers. It is obvious that only a small minority of the subscribers were medical men. From this, one may infer that physiognomics was not a specific medical issue, rather a subject that attracted the attention of a large general audience. A. Fokke Simonsz, a member of the learned society Felix Meritis in Amsterdam, prepared an essay Verhandeling over de algemeene Gelaatkunde (Treatise on the general physiognomy; 1801). A very interesting book was published by Antonie Martini van Geffen in 1825 in "s-Hertogenbosch, entitled De karakterkunde volgens de gelaatsleer, in verband beschouwd met de schedelleer en de menschelijke temperamenten (Characterology according to physiognomy, considered in relation to craniology and the human temperaments). Martini van Geffen (1791-1869), stemming from an affluent family, was a minister in a village, Vught, near 's-Hertogenbosch. In this book, Martini van Geffen explicitly attempts to combine Lavater's physiognomy with Gall's skull theory. 


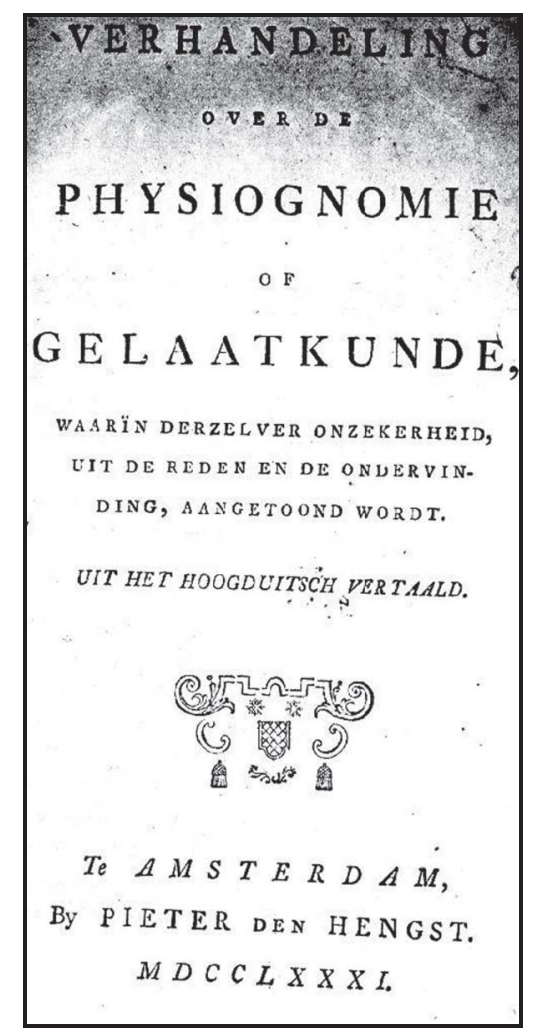

Figure 2. Title page of the translation of Chodowiecki's treatise.

Naturally, there are some differences, Martini van Geffen argues, but in principle the two frameworks attempt to explain human faculties and temperaments on the basis of particular physical features of the head. Martini van Geffen appreciated the possibility of integrating the two perspectives.

In summary, the general idea that one can deduce someone's character from one's appearance, in particular from the head or the face, was familiar to a large number of people in The Netherlands and apparently was a topic that attracted some attention in the form of public lectures and books. Gall's ideas about inferring faculties from the skull can be regarded as a specific alternative theory in this area of "anthropology," very much like Camper formulated a specific model based on the facial angle.

\section{Gall's Biography (Until 1805)}

Franz Joseph Gall was born on March 9, 1758 in Tiefenbrunn, close to Pforzheim, South Western part of Germany (Lesky, 1979). His father was a tradesman (who spelled his name as Gallo). From his early childhood on, Gall had a great interest in nature, both flora and fauna. Not only does his later work attest to this interest but also the beautiful gardens at his houses in Vienna and Paris.

Originally, Gall was destined for a religious position. Commencing in 1777, he studied medicine in Strassburg where Johann Hermann impassioned him to learn comparative 
anatomy. From 1781 onwards, he continued his studies in Vienna. His principle teacher there was Maximillian Stoll. He completed his dissertation in 1785 and started a private practice, attracting the attention of high society. His first work, Philosophisch-medizinische Untersuchungen über Natur und Kunst im kranken und gesunden Zustande der Menschen (Philosophical-medical studies on nature and art in disordered and healthy conditions), was published in 1791 and quickly displayed Gall's main interest.

From autobiographical remarks, we know that Gall already in his home in Vienna performed group studies about psychological faculties. He visited "the tower," the asylum for mental patients, to examine their physical appearance with specific attention to their heads. He was also interested in collecting skulls of important individuals. In 1796, Gall began his private lectures on Skull Theory or Organology, and these lectures attracted large audiences, including women of higher status and privileged backgrounds. Consequent to these lectures, the habit of feeling the lumps on the head and the production of demonstration heads developed. Kranioskopie became extremely fashionable.

\section{Gall as Anthropologist}

Throughout his work, Gall has indicated that his main objective was to investigate the true nature of man and to develop a "true theory of man." He hoped that such a theory would enable the creation of sociocultural changes for the benefit of everybody.

It is significant that the first real outline of his theory appeared in the form of a letter to his friend von Retzer in 1798 in a German newspaper, Teutschem Merkur. Baron von Retzer was an administrator working for the Vienna censorship and probably advised Gall to publish his ideas outside Austria. In his Program, the letter to von Retzer, Gall discussed his relationship with physiognomics (Lesky, 1979). He was very clear: "I am nothing less than a physiognomist" (Lesky, 1979, p. 57). Others have "baptized" his child cranioscopy, but he was not happy with that name. He was not primarily interested in the skull, but in the brain. Next to the brain was his interest in psychology. This probably stemmed from his observations and appreciation of human behavior as a child and an adolescent. At that time, Lavater's physiognomy became popular and Gall attempted to relate specific behavioral features to bodily characteristics; this continued to be Gall's central message in all his lecture series. It is noteworthy that his theory appeared more valuable to people working with criminals or children, than to physicians, who were interested in diseases and practical means to treating people inflicted with these diseases.

\section{The Tour}

On December 24, 1801, a handwritten order of the Emperor of Austria stated that the Chancellor of State, Earl Lazansky, prohibited the proclamation of Gall's theory, stating that people apparently ran the risk of losing their own head and that this theory could lead to materialism and to loss of interest in religion and moral principles. Many influential people tried to defend Gall, but with little success. The clerical group at the Vienna court, probably directed by the court physician Joseph Andreas Stifft, won the battle. On February 3,1802 , another decree prohibited the private lectures of Gall.

In 1805, Gall started his European tour that finished in November 1807 in Paris. The tour has been elaborately described by John van Whye (2002). ${ }^{1}$ He then traveled through

\footnotetext{
${ }^{1}$ The description can be retrieved from the internet at http://www.historyofphrenology.org. uk/texts.htm
} 
Italy, Germany, Denmark, Holland, and Switzerland. His arrivals were advertised in newspapers and we would now refer to this as "hype." The general pattern seems to be that in a particular place he presented a series of lectures, dealing with several aspects of his organology or craniology. The lectures tailored to a general audience. By and large, they were well received and the audience was very enthusiastic. If the interest for the lectures turned out extremely large, Gall stayed for another series.

Until 1810, when the first volume of his Anatomie et physiologie du système nerveux en général, et du cerveau en particulier (Anatomy and physiology of the nervous system in general, and of the brain in particular) (with J. C. Spurzheim, 1810-1819) rolled from a French press, most of what was known of his theories came from reports of his lectures, written by authors who took down what Gall had to say about brain function and its relation to the shape of the cranium. Between 1802 and 1810, a veritable procession of such reports appeared (e.g., Walter, 1802; Martens, 1803; Leune, 1804; Anonymus, 1805; Bischoff, 1805; Katejan Arnold, 1805; Kupf, 1805; Adelon, 1808). Not unlike present-day bootleg recordings of concerts, these reports were of uneven quality and some of them, for instance Ackermann (1806), were written with the explicit purpose of criticizing cranioscopy. From a commercial point of view, books on Gall's theory apparently were very successful: Several of them were translated or went through two or three editions.

At the same time, critics began to counteract. Among them were Ackermann, Hufeland, Walther, and Hegel (Wyhe, 2002). In Paris too, Gall had some important adversaries. Their influence was strong enough to keep Gall out of the French Academy of Sciences. A scientific committee with Tenon, Sabatier, Portal, Pinel, and Cuvier, (he, in particular, played a prominent role), to some extent influenced by Napoleon, had difficulties recognizing a clear relationship between Gall's anatomical views and his brain physiology (Lesky, 1979). Gall, on the other hand, did not want to assume an inferior role and preferred to remain independent and let the arguments in the paper and lectures do their work.

\section{Gall's Visit to The Netherlands}

Among historians of medicine, Gall's cranioscopic tour has received deserving attention, but only a passing reference is made to his sojourn in The Netherlands. Ebstein (1924) presented a minute report of Gall's dealings in promoting his theories, reconstructed from correspondence and diaries of his contemporaries, but he omitted the visit to Holland. We feel that this historiographical blank deserves to be filled. Several Dutch articles discussed Gall's visit to The Netherlands (Conradi, 1995; Steendijk-Kuypers, 1996; Heiningen, 1997). Drawing on journals and newspapers of that period, these authors have demonstrated that Gall's lectures stirred controversy among anatomists and public debates on the tenets of cranioscopy.

In the early spring of 1806, Gall visited The Netherlands. He delivered 10 lectures in Amsterdam and then five more in Leiden. Gall also proposed to give lectures in The Hague, but these were cancelled when it became clear there would not be enough subscriptions to fill a sizeable audience. Between and after the lectures, Gall visited Dutch learned societies. He met with several anatomists and inspected local anthropological collections and cabinets. In the last days of April, Gall left Holland and proceeded to Germany.

The furor that Gall had caused in Austria and Germany did not remain unnoticed in The Netherlands. As early as 1802, the Algemeene Konst- en Letterbode (General Magazine for Arts and Letters; see also Figure 3) published a one-page notice on Gall's 


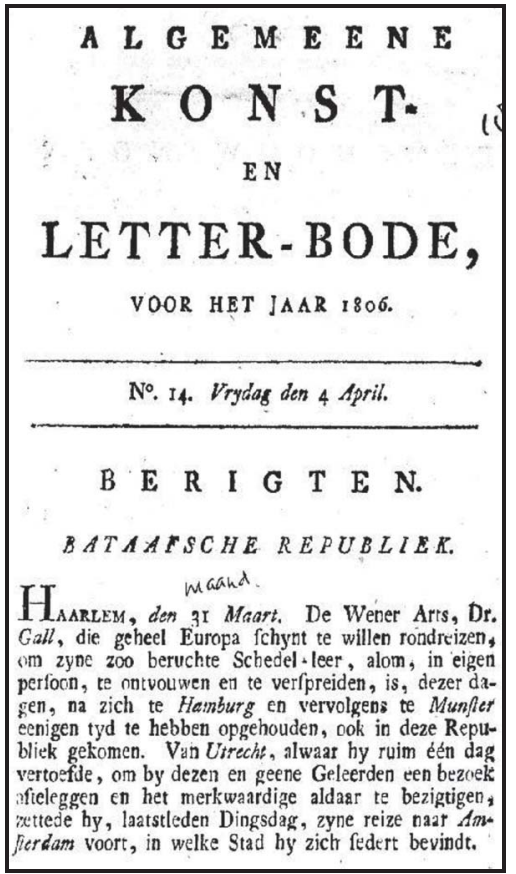

Figure 3. Announcement of Gall's arrival in Amsterdam in the newspaper Algemeene Konst - en Letterbode, Friday, April 4, 1806.The text indicates that Gall, the Viennese physician is travelling through Europe to explain his notorious theory. From Hamburg, he went to Munster and Utrecht and is now in Amsterdam.

views. The anonymous author stated - without comment - that the Viennese authorities had prohibited his public lectures and then proceeded to explain the cranioscopic theory. He mentioned some of Gall's findings in comparative anatomy, such as the discovery of the organ of musicality in the skulls of singing birds or the organ of cunningness in the skulls of cats and foxes. He also reported that Gall claimed to have found an excessively well-developed organ of musicality in Mozart's brain. The notice was phrased in the most cautious of terms: In the author's estimation cranioscopy was a "curious" theory; its validity, however, remained to be seen.

Fuller discussions of cranioscopy appeared two years later. In January 1804, Gerardus Vrolik (1775-1859), a Professor of Physics and Medicine at the Amsterdam Athenaeum Illustre, published Het Leerstelsel van Franz Joseph Gall (The Doctrine of Franz Joseph Gall). Vrolik's publication was based on his two lectures, given at the Felix Merites Society in Amsterdam. Vrolik referred to the facial angle of Camper and to Lavater's physiognomic system and he pointed to Gall's system as another possibility to gain more insight into the character of an individual. He offered some support for the implications it had for education and criminology, but for the present time he rejected the cranioscopically based method for diagnosing and predicting individual characteristics.

In December 1804, Jacob Elisa Doornik (1777-1837) published a highly critical examination of cranioscopy: De Herssen-Schedelleer van Frans Joseph Gall getoetst aan de Natuurkunde en wijsbegeerte (Franz Joseph Gall's theory on the brain and the cranium, tested by physics and philosophy; see Figure 4). Doornik held a professorship in medicine, 


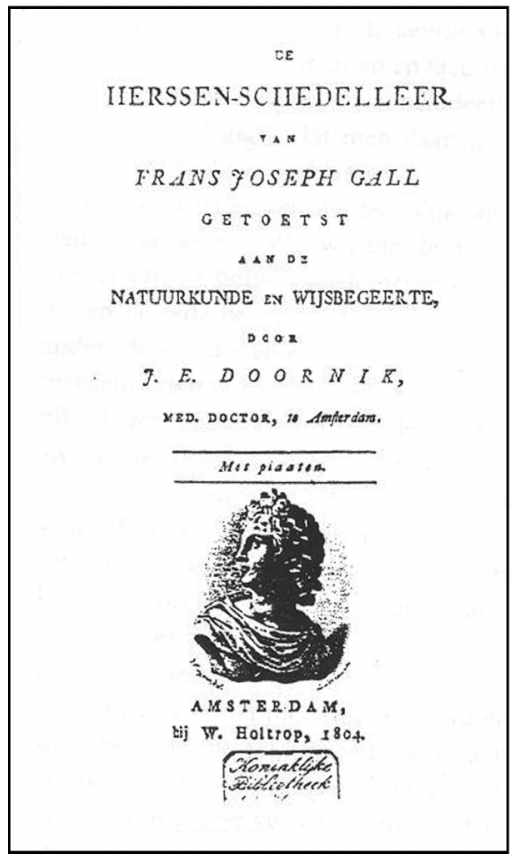

Figure 4. Title page of Doornik's book on Gall's craniology, evaluated in the light of physics and philosophy.

also at the Athenaeum Illustre. He had been present at Gall's lectures in Berlin and he criticized Gall for not providing evidence for his statements, for being materialistic, and for drawing tenuous conclusions. He argued that one should not judge a man on his talents but according to his works.

Later that month, the Remonstrant theologian Martinus Stuart (1765-1804) published his Dutch translation of Leune's Entwicklung der Gallschen Theorie über das Gehirn (Development of Gall's Theory of the Brain) (1803), prefaced by an extended and positive introduction (see Figure 5).

Vrolik and Doornik, even if they held opposite views on the value of Gall's theories, both had their books published by the Amsterdam publisher Holtrop. Apparently, Holtrop sensed a market for books on cranioscopy that he could monopolize on, regardless of their contents; a year later (1805), he published the Dutch translation of Doctor Gall auf die Reise, a comedy play by Wilhelm von Freygang, satirizing the touring Viennese anatomist (Freygang, 1805). In 1806, Holtrop completed a quartet of cranioscopic books by publishing two lectures on Gall, delivered by Doornik in the Amsterdam Society of Felix Meritis during the winter of 1805-1806. Doornik's judgment was, once again, vastly critical.

Gall, in the meantime, was held up in Germany for a series of extra lectures in Münster. Appetizing the audience, the Amsterdam newspaper De Ster published a few extracts from Gall's letters to his friends at Amsterdam. Gall indicated that his wish was to learn as well as to teach: He announced his intention to visit the famous anthropological cabinet of Petrus Camper and asked his friends to secure him as many "apes, parrots, big seaanimals or fish, dead or alive, as they could lay their hands on," in particular "the head of this orang-outang" (De Ster, 13 maart 1806, p. 13) he had heard about. As a sea-faring nation, he believed the Dutch were in a privileged position to gather a rich collection of rare 


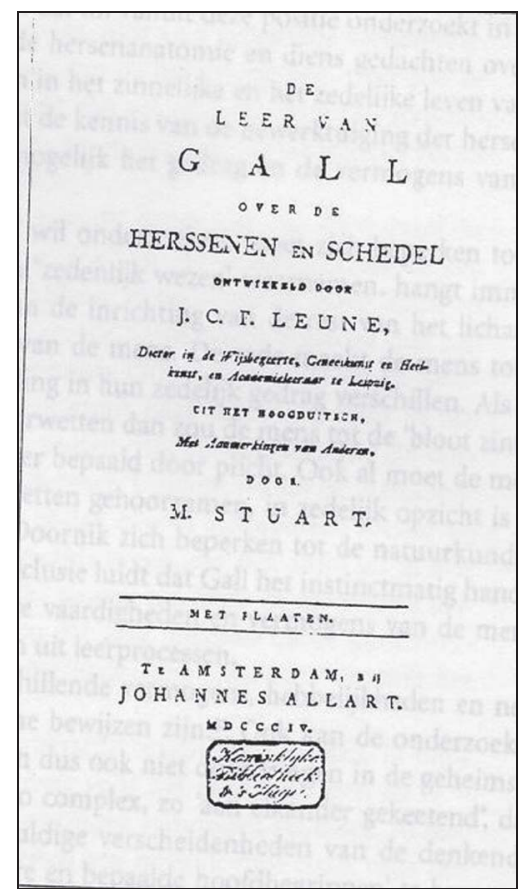

Figure 5. Title page of Stuart's book on the doctrine of Gall.

specimens from foreign countries. Apparently, his correspondents had signaled Gall that his views met with skepticism among anatomists, for he declared that he had nothing to fear "but Nature herself." In a second letter by Gall, he wrote that his extensive collection of demonstration material made traveling an elaborate enterprise, but that his skulls and anatomical preparations were essential for his lectures. He ended by requesting "three well furnished rooms with decent people, preferably in the center of Amsterdam." Those who wished to attend the lectures were invited to sign registers in the offices of De Ster, Felix Meritis, Doctrina, and the Leesmuseum ("Reading Museum"). The opening lecture was scheduled to take place on April 8, at $6 \mathrm{pm}$ in Het Wapen van Amsterdam. That evening, Gall welcomed approximately 100 audience members, who had paid 21 Dutch florins for a series of 10 lectures.

In conclusion, it appears that physiognomy as well as Gall's ideas were received well by theologians, while anatomically informed scientists were much more skeptical. Apparently, discussion of Gall's views took place in learned societies, opposed to physicians.

\section{Content of the Lectures}

The content of Gall's lectures in Amsterdam can be reconstructed from two sources. First, there are several short reports in the newspaper De Ster. In a report dated April 12, a certain G. discusses the three lectures Gall had delivered to that date. It seems G. was disappointed by Gall's style of lecturing. The long series of anecdotes, presented in a "coffee house conversation" kind of way, fell short of the standards for a "coherent, academic lecture" (De 
Ster, 12 April 1806, p. 118). Gall's sarcasms against anatomists and his repeated gibes at philosophers were uncalled for. He ridiculed his opponents, putting in their mouth the grotesque claim that if he, Gall, was right, midwives might very well correct nature by pushing away evil organs, or lifting good organs elsewhere. Three days later, G. wrote a second report that was much more favorable. He now praised Gall's "immortal discoveries," the fruit, no doubt, of "German tenacity and patience." Just when his knowledge of human anatomy and physiology seemed exhausted, he went on, Gall presented a "rich harvest." On April 17, De Ster published a report by G. on Gall's sixth lecture, dealing with the organ of procreation or amativeness (Number 1 on the cranioscopic map). G. appears to have been quite impressed: Drawing on mythology, paintings, and descriptions of nymphomanic patients, Gall had proved, to G.'s satisfaction at least, that this particular organ indeed had its seat in the back of our heads.

The second source on Gall's lectures is Stuart's book Herinneringen uit de lessen van Frans Joseph Gall (Memories from the lessons of Franz Joseph Gall), which appeared in 1806. Stuart had been in the audience in Amsterdam and he presented a full report of each of the 10 lectures. In the dedication (to an anonymous gentleman), he wrote that Gall spoke very fast, defying all efforts to write a verbatim report. Stuart could not convey what Gall had pointed out on the demonstration material he had with him, such as skulls, drawings, and wax models of animal and human brains. Despite these shortcomings, Stuart's report of 133 pages is fairly rich in detail.

Those in the audience, who had come to know about the exact cranial locations of the human faculties, the most notorious part of Gall's doctrine, had to sit and be patient. Before dealing with cerebral topography, Gall wished to discuss some preliminary matters. Cranioscopy, he argued, was a misnomer: His theory was intended to explain the development of the brain as an organ of our mental faculties. The brain serves our mind as its material condition, much as the eye is the corporeal condition for sight. Gall then pointed out that the various organs indicated penchants and instincts but were not the cause of behavior. Our acts, as he explained, are under the control of the mind and therefore guided by moral restraints. Man is by no means forced to act on his impulses. Further on in his lecture, as well as in lectures to follow, Gall referred time and again to this important point. His doctrine was partly materialistic, he granted, since it dealt with the material conditions of thought and behavior, but it was certainly not fatalistic. The material nature of our cerebral organs leaves our moral freedom intact. In other words, charges of atheism were completely unfounded. These were, of course, the words of a cautioned man. Allegations of atheism had led to the ban of his lectures in Austria and for Gall, who probably lived on this income, experienced further problems with authorities abroad with the threat of jeopardizing the tour as well as his greater cause. Therefore, Gall requested that his listeners agree that God had created a natural world and a moral world, and that a truth in the former world could not contradict a truth in the latter world.

After clearing these two misunderstandings, Gall went on to argue that the brain, like so many human organs, was a double organ. Moreover, each half consisted of specialized parts. Lesions at different locations produced a variety of impairments. These selective disturbances proved that the brain — and similarly the mind — was a divided entity. The unity of consciousness was not a valid argument against the theory of the double brain, any more than the unity of sight substantiates that we have only one eye. In this way, most of the first lecture went away with a general defense of the doctrine against the charges of philosophers, metaphysicians, fellow anatomists, and other adversaries. It also determined the blueprint for the next four lectures.

In his second lecture, Gall argued that the human soul is not the undivided entity that philosophers have made it to be. Just as our sensory perceptions originate from separate 
senses, the various mental faculties originate from separate organs in our brain. Each of these organs has its own neuronal connections and locations. Gall held up a wax-coated brain, pointing out the separate courses of nerve fibers. Mental faculties differ from person to person and even within the same person during the course of his life. The cerebellum for instance, organ of amativeness, is very small in childhood but shows a disproportionate growth during adolescence. The third lecture took this theory two steps further: (a) the size of an organ is a measure of its strength, and (b) size can be determined from the outside, by touching the surface of the skull, preferably with the flat hand. During the embryonic phase, the formation of the bones of the skull faithfully follows the shape of the brain. At a later stage - and even in old age - natural metabolism allows the skull to adapt its form to the size of the organs. Passing along the skull, Gall invited his audience to see for themselves that specific faculties reveal themselves in bumps.

Having demonstrated that some talents are truly outstanding in more than one sense of the word, Gall stated in his fourth lecture that there is a global relationship between the size of the brain and the level of intellect. On average, the skull of a child of superior intellect will be larger than the skull of his less-endowed peer. Skulls of people from "primitive cultures" are smaller than European skulls. Gall claimed to have performed autopsies on the brains of 300 mental patients, finding that they all had "soft brains and tough skulls" (Stuart, 1806, p. 32). Thick skulls were presumed to harm the brain. This is especially relevant in forensic matters. Gall recommended that judges should keep in mind that both infanticide and suicide may be caused by brain diseases.

The audience in the fifth lecture found the Viennese anatomist still dealing with preliminaries. First, he discussed the criticisms of Ackerman, Plattner, and others. Gall minced no words: These men were all misguided, ill-informed, or plain incompetent. If it were not for their deserved reputation in other fields, Gall confided to his audience, he would have refuted them in print long ago. His own research was methodologically impeccable. He explained that he looked for resemblances in the skulls of geniuses in one particular area and tested his hypotheses against the skulls of people, who lacked this specific talent. He also referred to his numerous autopsies, both on human and animal brains. It is clear that Gall took great pride in his understanding of comparative anatomy.

Finally, in the sixth lecture, Gall started with a discussion of separate organs and their location. The first on Gall's catalogue was the double organ for amativeness. It could be felt as two swellings at the back of the head. Why should there be such a well-protected position for such a "low" organ? Gall argued that nature may have her own scheme of values, perhaps she feels that the organ regulating reproduction is more vital to man than his organ for reflective thought. The evidence Gall put forward was essentially a heap of facts and observations, mixed with anecdotes. The growth of the cerebellum is proportional to the development of sexual maturity. A "hysteric woman" with exceptionally intense sexual urges had a "burning" back of the head. Men have broader necks than women, in accordance with their greater sexual appetite. At stud-farms, there is a marked preference for horses with broad necks. Turkish men have broad necks, which betray their polygamic nature. After castration the cerebellum shrinks. Excessive stimulation of the neck, as happens in a hanging, may cause an erection. All in all, Gall adduced no less than 13 arguments in favor of the back of the head as the seat of amativeness.

The next four lectures were devoted to the next 26 organs on Gall's list. Immediately above the two bumps of amativeness was a single bump, corresponding to the organ for the "love of children." In passing, Gall laid down the general rule that insanity will always strike at the most prominent organ. In an Amsterdam asylum, he said, he had put this hypothesis to the test in the presence of professor Vrolik. Working from the back of the 
head to the front, Gall presented his evidence for the various organs of memory (for instance memory for places, language, numbers, colors, etc.). An exceptional ability to memorize revealed itself in protruding eyes (the famous Amsterdam actor Cruys, Stuart added, was certainly a case in point.) Subsequently, Gall detailed all the remaining parts of the cranial map, discussing organs like acquisitiveness, reverence, mirthfulness, benevolence, and secretiveness. There could not be more organs, Gall claimed, nor less; these 26 organs just presented themselves to his inquisitive eyes; they were truly "found." If such a relatively small number of organs seemed insufficient to account for the rich variety of human behavior and personality, one should reflect that music, calculation, and all manner of writing are equally built on a limited number of elements. Ending on a pious note, Gall explained to his Amsterdam audience that we owe our human nature to the sophisticated construction of the brain, which testifies to the "perfect work" of a holy, wise, and loving God.

\section{Reception}

As indicated above, there was a clear interest in physiognomy in The Netherlands. In the 1780s, a number of books were published, suggesting that Lavater's views were well received. Lavater died in 1800 and interest in his work was resurrected. However, it is important to note that the audience was more one of educated men in general than specifically of physicians. As described above, in the second edition of the Dutch translation of Lavater's book (Lavater, 1780), a list of subscribers is included, and physicians apparently are a very small minority. Brain anatomy is clearly missing in the many books that were published during Gall's tour to promote his theory. The audience was more interested in the implications of the theory than in the structure of the brain. Physiognomy was regarded to reveal something about an individual's character or personality. It may be relevant for interpersonal communication, rather than for understanding and treating diseases. Another area, in which it played a significant role, was criminology with the central question being whether there was a biological basis for criminal behavior.

This latter aspect can also be found in the works of Gall. The basic motive for Gall's undertaking was his wish to develop a psychological framework. Moreover, he was not just interested in "classical" psychological faculties such as perception, imagination, and memory; he certainly devoted much attention to "moral" qualities. And these moral qualities could be linked to actual behavior, including misconduct. In his quest to explore morality, Gall ventured to prisons to examine the skulls of criminals. Gall's views were also tested by presenting him the skulls of criminals.

When the initial reports of a new theory on how to deduce a man's character from the skull reached The Netherlands in the early years of the nineteenth century, people were more or less familiar with the general purpose of this theory. An important distinction is that Lavater looked at the "weak parts" of the facial part of the head, whereas Gall concentrated on the skull (Martini van Geffen, 1825).

Gall's theory undoubtedly suffered from many weaknesses. His psychological organs did not follow from a well-developed philosophical system but were found more or less by serendipity. The evidence was weak: anecdotes of individuals with a bump, detected only by Gall himself. Contrary evidence of others with similar behavior, but lacking the bump at the required site, was not accepted as counterproof by Gall. Anatomically, the theory also did not rest on a convincing basis: How can one detect bumps at places where there is no cortical tissue lying beneath? Or, why are there only bumps at places that we can touch, but not at the bottom of the skull? Scientists, familiar with the human brain, 
not only detested Gall's materialistic and fatalistic views but they also were aware of the lack of philosophical and empirical support. The following anecdote may illustrate this. When Gall himself came to The Netherlands, he was invited by members of a learned society in Amsterdam. On his way to Amsterdam, he paid a short visit to Utrecht, where he apparently met Mathias van Geuns, a Professor of Medicine. Van Geuns apparently did not think highly of Gall and it was made very clear in his interactions with Gall. According to Steendijk-Kuypers (1996, p. 2563), Van Geuns kept Gall waiting for over an hour and then welcomed him as follows: "You are Doctor Gall, who formulated the craniology, but I must confess to you directly that I do not have a great respect for this theory" (our translation from the German citation). He then presented Gall to the head of the botanical garden and left.

The next day, Gall continued his journey to Amsterdam. From the description in the newspaper articles, it is clear that the audience was not very enthusiastic about Gall's presentations. They did not meet the expected standard of a scientific lecture. Moreover, Gall could not deal with critical questions and thus gave others the impression that he thought too highly of himself and was reluctant to accept constructive criticism. However, there exist reports that seem somewhat more favorable. History repeated itself in Leiden. His lectures were not well appreciated. Gall quickly had enough of the Dutch, and the feeling was mutual. Very little interest in his work is discernible after 1806.

References to Gall's work remain scarce indeed and are generally not found in medical contexts. In 1809, a review was published of a German play Dr. Gall and Dr. Faust (Oemler, 1808). The play highlights that interest in Gall's skull theory was minimal. As mentioned above, Martini van Geffen published his Schedelleer en het Menselijke temperament (Skull theory and the human temperament) in an attempt to integrate Lavater's and Gall's theories (see Figure 6).

In 1819, three young medical students (Broers, de Fremery, and Tilanus) went on a study tour to France and Germany (van Mesdag, 1927). The diary of that trip was never published, but short excerpts were available in an article published in a criminological journal in 1927. It appears that the three had a specific interest in criminology and also visited some jails. They attended four lectures Gall gave at the Athenée in Paris. The contents of these lectures resemble the lectures Gall gave on his tour between 1805 and 1807 . There are no indications that Gall's lectures had a great impact on these young men and had any further influence when they pursued their medical profession upon their return home.

Schroeder van der Kolk, who is perhaps considered the founding father of psychiatry and neurology in The Netherlands (Eling, 1998) was aware of Gall's work. We only found a few places where he refers to Gall's "craniological views." It is interesting to note that Schroeder appears to have accepted the notion of localization of function - in some sense - before the decisive discussion was started by Broca in 1861. In his Handboek van de Pathologie en Therapie der Krankzinnigheid (Handbook of Pathology and Therapy of Madness; Schroeder, 1863), edited and published after Schroeder's death by his colleague and friend Hartsen, he wrote about the different roles or functions of various parts of the cerebral hemispheres. He argued that it was already suspected for a long time that the frontal part of the brain was associated with intellectual functions. Next to Camper, he refers to Gall, "who, even though he placed his organs rather arbitrarily, also localized the most important organs for higher intellectual functioning behind the forehead" (Schroeder van der Kolk, 1863, p. 37). Apparently, Schroeder too was critical of details of Gall's views, but he still regarded Gall's work as a valid reference for the localization of functions in the brain. 


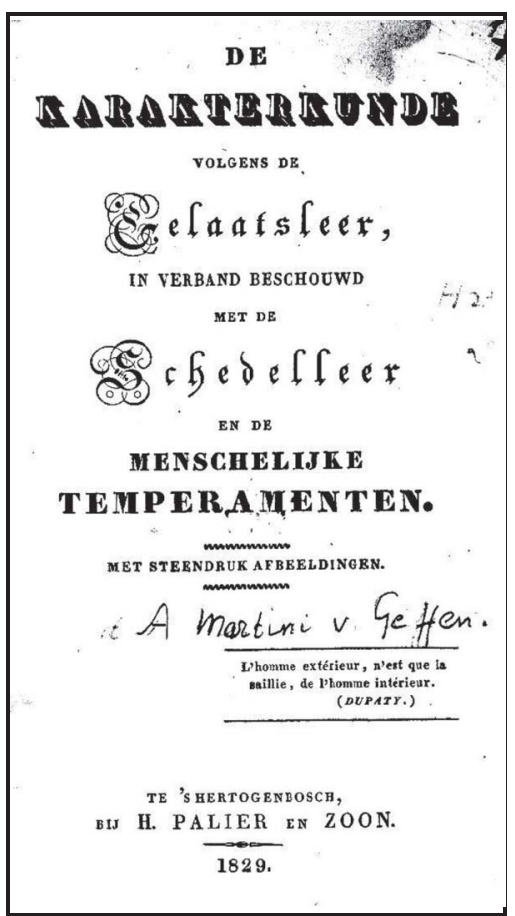

Figure 6. Title page of A. Martini van Geffen's book on physiognomy in relation to Gall's craniology.

Capelle (1854) published an extended essay in a literary journal entitled De Gids (The Guide). The purpose of the essay was to introduce the views of the German physician Carl Gustav Carus (1789-1869) to a wide audience. One wonders whether Van Capelle's motivation was to get his paper published in a medical journal. In this essay, Van Capelle also mentioned Gall's "theory of organs" and claimed that it had already been rejected for a long time, as it had been proven to be built on "false" premises.

Nevertheless, Thijssen (1858) seriously attempted to raise some support for Gall's theory. He must have been familiar with it as he competently discusses many weaknesses and inconsistencies. Although it had been rejected a long time ago, Thijssen assumed that it was generally known among his readers, a nonspecializing audience. Very much like current authors have resurrected the statue for Gall as the man, who introduced the principle of localization of (more or less independent) faculties on the cortex of the brain, so Thijssen pointed out that no one could seriously refute the general principle. Of course, one may have problems with the specific mental faculties that Gall distinguishes and one may even point out the anatomical absurdities put forth by Gall; however, it is the general principle that may have served as the starting point for the study of the biological foundation of psychological functions. After having discussed various aspects, Thijssen raised the following question:

So what remains, after all, of this entire system of Phrenology, of Gall himself? ... I remember this sea of foolishness I had to go through, before I arrived at Gall himself, and still I recollect clearly how gratefully I admired this great 
man, who was the first to clearly explain how the soul reveals itself out of the cerebral and spinal nervous system. (1858, p. 198)

Thijssen's plea enjoyed little success. Interest in measuring the skull only revived when Lombroso became popular towards the end of the nineteenth century. In The Netherlands, Winkler became highly interested in this phenomenon. Winkler considered Lombroso to be his friend. He also published studies in this area (Draaisma, 1995). However, Gall did not play a role in these discussions.

In retrospect, Gall appears to have "sown" in a rather infertile Dutch soil. His audience was a bit skeptical from the beginning. Gall's personal attitude seems to have played an important role, too. It should be noted that Dutch scientists were rarely examining the relationship between brain and behavior in an empirical way. While heated discussions on the issue of localization of function took place in France, Germany, and England, hardly any serious scientific papers on this topic was written in The Netherlands (Eling, 2008).

\section{References}

Ackermann JF (1806): Der Galllsche Hirn-Schedel- und Organenlehre vom Gesichtspunkte der Erfahrung aus beurtheilt und widerlegt. Heidelberg, Mohr und Zimmer.

Adelon NP (1808): Analyse d'un cours du docteur Gall. Paris, Giguet et Michaud.

Anonymous (1780): Physiognomische Catechismus, bevattende de gronden en beginselen der Gelaadkennis [Physiognomic Catechism, containing the reasons and principles of Physiognomy]. Amsterdam, Gerrit Bom en Zoonen.

Anonymus (1805): Ausführliche Darstellung des Galllschen Systems der Schädellehre. Magdeburg, S.N.

Bacon F (1994): The Advancement of Learning. Whitefish, Montana, Kessinger Publishing.

Bischoff CHE (1805): Darstellung der Gall'schen Gehirn- und Schädellehre. Berlin, S.N. (unknown).

Broca P (1863): Localisation des fonctions cérébrales. Siège du langage articulé. Bulletins de la Société d'Anthropologie. Séance du 2 Avril 1863: 200-204.

Capelle H van (1854): De symboliek van den schedel [The Symbolism of the Skull]. De Gids 18: 433-461.

Chodowiecki D (1781): Verhandeling over de physiognomie of gelaatkunde [Treatise on the physiognomy of the face]. Amsterdam, P. de Hengst.

Conradi M (1995): Franz Joseph Gall in Nederland. De Psycholoog 7: 320-323.

Doornik JE (1804): De Herssen-Schedelleer van Frans Joseph Gall getoetst aan de Natuurkunde en Wijsbegeerte. Amsterdam, Holtrop.

Doornik JE (1806): Voorlezingen over F. J. Gallls herssen-schedelleer. Amsterdam, Holtrop.

Draaisma D (1995): De Hollandse Schedelmeesters. Lombroso in Nederland. Feit en Fictie 2: 50-73.

Ebstein E (1924): Franz Joseph Gall im Kampf um seine Lehre. In: Singer C, Sigerist HE, eds., Essays on the History of Medicine. Zürich, Seldwyla.

Eling P (1998): Jacobus Schroeder van der Kolk (17-1862): His resistance against materialism. Brain and Cognition 37: 308-337.

Eling P (2008): Cerebral localization in The Netherlands in the 19th century, emphasizing the work of Aletta Jacobs. Journal for the History of the Neurosciences 17: 175-194.

Fokke Simonsz A (1801): Verhandeling over de algemeene Gelaatkunde [Treatise on the general Physiognomy]. Amsterdam, S.N.

Freygang W von (1805): Doctor Gall op reis: blijspel in één bedrijf. van Esveldt, JS, trans. Amsterdam, Holtrop. 
Gall FJ, Spurzheim JC (1810-1819): Anatomie et physiologie du système nerveux en général et du cerveau en particulier; avec des observations sur la possibilité de reconnaître plusieurs dispositions intellectuelles et morales de l'homme et des animaux par la configuration de leur têtes, volumes $1-4$ and atlas. Paris, F. Schoell.

Heiningen T van (1997): De receptie van de hersen-schedelleer van Franz Joseph Gall in Holland kort na 1800. Gewina 20: 113-128.

Jahnke J (1997): Physiognomy, Phrenology, and non-verbal communication. In: Bringmann, WG, Lück H, Miller R, Early Ch, eds., A Pictorial History of Psychology. Chicago, IL, Quintessence Publishing Co.

Kajetan Arnold JTF (1805): Dr. Joseph Gallls System des Gehirn und Schädelbaues. Erfurt, Henning.

Kruger L (2005): The scientific impact of Dr. N. Tulp, portrayed in Rembrandt's "Anatomy Lesson." J Hist Neurosci 14(2): 85-92.

Kupf M (1805): Beleuchtung der Gall'schen Gehirn- und SchäcZellehre durch Vernunft: und Erfahrung geleitet. Berlin, S.N.

Lavater JK (1775-1778): Physiognomische Fragmente zur Beförderung der Menschenkenntnis und Menschenliebe. Leipzig - Winterthur: Bey Weidmanns Erben und Reich, und Heinrich Steiner und Compagnie.

Lavater JK (1780): Over de Pysiognomie door J.C. Lavater. Amsterdam, Johanes Allart.

Lesky E (1979): Franz Joseph Gall (1758-1829): Naturforscher und Anthropologe. Bern, Huber.

Leune JCF (1804): De leer van Gall, over de hersenen en schedel. Stuart M, trans. Amsterdam, Allart.

Martens FH (1803): Leichtfassliche Darstellung der Theorie des Gehirn- und Schädelbaues des Dr. Gall. Leipzig, S.N.

Martini van Geffen A (1825): De karakterkunde volgens de gelaatsleer, in verband beschouwd met de schedelleer en de menschelijke temperamenten [Characterology according to physiognomy, considered in relation to craniology and the human temperaments]. 's-Hertogenbosch, Palier en Zoon.

Noordhoek WJ (1925): Lavater und Holland. Neophilologus 10: 10-19.

Oemler CW (1808): Doctor Gall en doctor Faust, of, De groote omwenteling op aarde. Fokke Sz A, trans. Amsterdam, Timmer.

Porta G B Della (1586): De humana physiognomonia. Aequensis, J. Cacchius.

Schroeder van der Kolk JLC (1863): Handboek van de Pathologie en Therapie der Krankzinnigheid [Handbook of Pathology and Therapy of Madness]. Utrecht, van der Post.

Schuller tot Peursum-Meijer J, Koops WRH, eds. Petrus Camper 1722-1789, onderzoeker van nature [Petrus Camper 1722-1789, an inveastigator by nature]. Groningen, S.N.

Steendijk-Kuypers J (1996): Het succes van een dwaling. De hersen-schedelleer van Franz Joseph Gall (1758-1828) en de echo van de frenologie in Nederland. Nederlandsch Tijdschrift voor Geneeskunde 140 (51): 2560-2564.

Stuart M (1806): Herinneringen uit de lessen van Franz Joseph Gall. Amsterdam, J. W. IJntema.

Thijssen HF (1858): Over de leer van Gall. De Gids 10: 145-214.

Van Mesdag S (1927): Een criminologische bijdrage van het jaar 1819 [A criminological contribution from the year 1819]. Tijdschrift voor Strafrecht 37: 189-209.

van Wyhe J (2001): [Online]. Travels of a Craniologist: Franz Joseph Gall and his European lecture tour, 1805-1807. Available: http://www.historyofphrenology.org.uk/texts.htm

van Wyhe J (2002): The authority of human nature: The Schäellehre of Franz Joseph Gall. British Journal of the History of Science 37: 17-42.

Vrolik G (1804): Het leerstelsel van Franz Joseph Gall. Amsterdam, Holtrop.

Walter JG (1802): Kritische Darstellung der Gallsche Aantomisch-Physiologische Untersuchungen des Gehirn- und Schädelbaues. Zürich, S.N. 